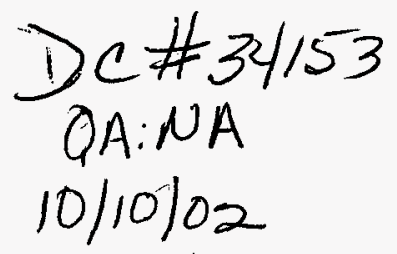

\title{
CONSTANT LOAD SCC INITIATION RESPONSE \\ OF ALLOY 22 (UNS N06022), TITANIUM GRADE 7 AND STAINLESS STEELS AT $105^{\circ} \mathrm{C}$
}

\author{
L.M. Young, G.M. Catlin, P.L. Andresen \\ GE Global Research \\ 1 River Rd. \\ Schenectady, NY 12301
}

\author{
G.M. Gordon \\ Framatome ANP \\ 1180 Town Center Dr. \\ Las Vegas, NV 89144
}

\begin{abstract}
This paper provides an update on research addressing the effects of material condition and applied stress on stress corrosion cracking (SCC) in waste package and drip shield materials for the Yucca Mountain Project. Time-to-failure experiments are being performed on smooth bar tensile specimens in a hot, concentrated, mixed-salt solution chosen to simulate concentrated Yucca Mountain water. The effects of applied stress, welding, surface finish, shot peening, cold work, crevicing, and aging treatment are being investigated for Alloy 22 (UNS N06022). Aging treatments were designed to produce topologically close-packed phases (TCP) and long-range ordering (LRO) and are under investigation as worse-case scenarios for possible microstructures in Alloy 22 (UNS N06022). Titanium Grade 7 and 316NG stainless steel are included in the matrix, as they are identified for drip shield and waste package components, respectively. Sensitized 304SS specimens are included in the test matrix to provide benchmark data. This research complements high-resolution crack-growth-rate experiments currently being performed in a parallel research project.
\end{abstract}

\section{INTRODUCTION}

General corrosion, localized corrosion, and stress corrosion cracking represent the most likely degradation modes for nuclear waste package structural materials. Since the waste package will always be hotter than its surrounding environment, the solution composition on the waste package surface will concentrate as the waste package initially cools to the temperature of the maximum boiling point elevation. As the Yucca Mountain water drips or splashes onto the drip shield and later onto the waste package where it concentrates, the $\mathrm{pH}$ of typical carbonate-rich seepage water is expected to rise to at 
least 10 and perhaps higher. This research study is designed to use a statistical approach in determining the life and reliability of proposed waste package materials potentially susceptible to stress corrosion cracking under environmental conditions that are both relevant and likely to promote stress corrosion cracking, i.e., fairly high solution concentrations at fairly high temperatures. The experimental results will provide a means of making probabilistic comparisons between material-conditions. These data will be strengthened with laboratory crack growth data obtained in a parallel study [1,2]. Other programs are addressing the general and localized corrosion in this and related environments [3-6].

\section{EXPERIMENTAL PROCEDURE}

Time-to-failure experiments are being performed on smooth tensile specimens that are individually loaded by the internal pressure of a large "Keno" autoclave. A schematic of the Keno autoclave cross-section is shown in Figure 1. The 347SS autoclave has a volume of 68 liters, which is filled with mixed salt solution. The composition of the mixed salt solution used in this study was chosen to simulate concentrated Yucca Mountain water (Table 1). Three 304SS manifolds are loaded into the Keno autoclave, where each manifold can support fifty 304SS specimen module assemblies (for a total of 150 specimens). A schematic of a module assembly is shown in Figure 2. The load on each specimen is created by the pressure differential across a sliding seal on a piston connected to the specimen, where internal pressure of the autoclave is on one side and atmospheric pressure is on the other side of the manifold. A pressuring gas is used to create the internal pressure in the autoclave due to the lack of substantial vapor pressure at $105-125^{\circ} \mathrm{C}$. On specimen failure, the piston and specimen cause a numbered indicator ball (i.e., "Keno") to be ejected into the manifold. The indicator ball runs down the manifold into a track, past a sensor (which records the time of failure), and into a tube where it is stored so that the failure sequence is known.

Two runs of Keno testing were performed. A small initial matrix of 50 specimens was tested first at $125^{\circ} \mathrm{C}$. The results from this small matrix were used to determine the stress levels and material conditions used in the following larger scale run ( 150 specimens) performed at $105^{\circ} \mathrm{C}$. Time-to-failure results are plotted as a function of the ratio of applied stress to yield stress in an attempt to normalize the large differences in yield strength between materials used in the study. Tensile tests were performed on one specimen per metallurgical condition in $105^{\circ} \mathrm{C}$ or $125^{\circ} \mathrm{C}$ air to determine applicable yield strength values. Yjeld strength values that are used in ensuing time-to-failure plots are presented in Table 2.

\section{RESULTS}

Initial Matrix Run 1 at $125^{\circ} \mathrm{C}$

A small initial matrix of 50 specimens (Run 1) was tested first at $125^{\circ} \mathrm{C}$. The results from this small matrix were used to determine the stress levels and material conditions used in the ensuing larger scale run (150 specimens) performed at $105^{\circ} \mathrm{C}$. 'The initial matrix of specimens (Run 1 ) is shown in Table 3. In addition to the as-received Alloy 22 (UNS N06022) and as-received Titanium Grade 7, 20\% cold worked specimens and as-machined + shot peened specimens of both materials were also tested. Additionally, type $316 \mathrm{NG}$ stainless steel in the as-received and shot peened conditions was tested. Finally, as a reference / baseline condition, sensitized type 304 stainless steel was tested in the asreceived and shot peened conditions. Shot peening was performed on the as-machined and cleaned specimens using GP60 glass pellets to an intensity of 6-8 N (several thousands of an inch depth). 
As expected, the sensitized 304 stainless steel specimens failed at the lowest applied stresses (54$60 \mathrm{ksi})$ and lowest failure times $(0.5$ to $285.9 \mathrm{hrs})$, as shown in Figure 3. Fracture surfaces for these specimens exhibited an intergranular morphology, as shown in Figures $4 \mathrm{a}$ and $4 \mathrm{~b}$. The Titanium Grade 7 specimens (as-received and as-received + shot peened conditions) also failed early in testing ( 0.7 to $49.8 \mathrm{hrs}$ ) and at relatively low applied stress (49-56 ksi), although at higher applied \%TS than the sensitized 304 stainless steel specimens (92-100\% vs. $72-80 \%$, respectively). Examples of the typical transgranular SCC fracture surfaces for the Titanium Grade 7 specimens are shown in Figures $4 \mathrm{c}$ and $4 \mathrm{~d}$.

The Keno system was depressurized and cooled after $885.5 \mathrm{hrs}$ of total testing to investigate the degree of salt encrustation and possible negative effects on ball drop. Inspection of the type 304SS manifold and modules revealed some isolated areas of severe corrosion and encrustation. A total of twenty specimen failures were observed in the manifold, but salt deposits had prevented ball drop in 5 instances (and thus prevented recording of the failure time). The $S$ unrecorded failures are noted in Figure 3. The twenty failures included all the as-received and as-received + shot peened Titanium Grade 7 and sensitized 304 stainless steel specimens. Temperature settings were lowered from the initial $125^{\circ} \mathrm{C}$ to $105^{\circ} \mathrm{C}$ to eliminate boiling of solution as it escapes past the seals on specimen failure, thus reducing the formation of the salt deposit in the manifold. Cumulative experiment time was restarted at $885.5 \mathrm{hrs}$ in parallel with returning the autoclave pressure to $1000 \mathrm{psi}$. No additional failures occurred at 1000 psi. Pressure was increased to 1100 psi at 1003.5 hrs. No failures occurred during the $318 \mathrm{hrs}$ at $1100 \mathrm{psi}$.

At $1321 \mathrm{hrs}$, the system pressure was increased to $1200 \mathrm{psi}$. Several cold worked Titanium Grade 7 and $316 \mathrm{NG}$ stainless steel (both the as-received and shot peened conditions) failed over the next several days due to problems with the pressure regulator (specimen failure stresses are included in Table 3). These failures are likely overload failures. The sensitivity and instability of the pressure regulator worsened with time. Additionally, pressure drift increased vs. time, and was especially pronounced after the addition of new solution, presumably because of the reduced gas space in the autoclave. It is likely that the $310 \mathrm{NG}$ stainless steel specimens failed by ductile overload. Although the ultimate tensile strength of $316 \mathrm{NG}$ was not measured in this program, an average value for three heats of $316 \mathrm{NG}$ stainless steel suggests an ultimate tensile strength of $\sim 75 \mathrm{ksi}$ at $\sim 100^{\circ} \mathrm{C}$. Failures occurred between 1412 and $1524 \mathrm{hrs}$ (one failure occurred at 1922 hours). The system pressure during this time period was $\sim 1200$ to $1300 \mathrm{ksi}$, translating to applied specimen stresses between 68 to $75 \mathrm{ksi}$. An appearance reflective of ductile dimpling was observed by scanning electron microscopy, confirming overload failure. Typical images representative of the failure surfaces for the overloaded $316 \mathrm{NG}$ stainless steel specimens are presented in Figure 5a and $5 \mathrm{~b}$.

At $1922 \mathrm{hrs}$, the system pressure during Initial Run 1 drifted up to $1600 \mathrm{psi}$, which overloaded most of the remaining unfailed specimens. Thirteen specimens failed during the overload, including the as-received Alloy 22 (UNS N06022) (6 specimens), as-received + shot peened Alloy 22 (UNS N06022) (4 specimens), the remaining cold worked Titanium Grade 7 ( 2 specimens) and the last $316 \mathrm{NG}$ stainless steel specimen. Only the $20 \%$ cold worked Alloy 22 (UNS N06022) (6 specimens) remained unfractured. The system pressure reached $1600 \mathrm{psi}$ due to problems with the regulator, translating to an applied stress of $111-117 \mathrm{ksi}$ (depending on the exact gage diameter) for the Alloy 22 (UNS N06022) specimens (all conditions). The $125^{\circ} \mathrm{C}$ air tensile strengths for the as-received and cold worked Alloy 22 (UNS N06022) were $104 \mathrm{ksi}$ and $133 \mathrm{ksi}$, respectively (also measured in this program using the same specimen geometry). The tensile strength for the cold worked Alloy 22 (UNS N06022) specimens was not exceeded during the overload; these 6 specimens are the only ones that did not fail in Run 1 . 
Microvoid coalescence typical of ductile overload failure is the dominant fracture feature for the overloaded Alloy 22 (UNS N06022) specimens; typical examples are presented in Figures 5c and 5d.

Despite the experimental challenges encountered during the Preliminary Run 1, useful SCC information was still obtained. The SCC resistance of Alloy 22 (UNS N06022) is evident in the plot of failure stress vs. time-to-failure in Figure 4. Alloy 22 (UNS N06022) specimens exhibited the highest failure stress and longest time-to-failure. All of the Alloy 22 (UNS N06022) failures that occurred at 1922 hrs were due to the system overload and not due to SCC (the cold worked Alloy 22 (UNS N06022) specimens did not fail). Statistical analysis using a Weibull distribution indicated that shot peening did not significantly affect time-to-failure for sensitized 304SS or Titanium Gr 7.

\section{Full Matrix Run 2 at $105^{\circ} \mathrm{C}$}

The full matrix (Run 2) allowed investigation of the effect of material, applied stress, welded regions, crevice geometry, surface finish, cold work, and aging treatments designed to produce topologically close-packed phases (TCP) and long range ordering (LRO) in Alloy 22 (UNS N06022). Multiple gage diameters and crevice/uncreviced conditions for Ti Grade 7, 316NG SS and sensitized 304SS were also included in the full matrix. Gage diameters were increased for the $\mathrm{Ti}$ Gr 7 and sensitized 304SS specimens in the full matrix (Run 2) compared to the initial small matrix in order to reduce infant mortality failures observed in Run 1 (corresponding applied stress levels shown in Tables 3 and 4).

Applied heat treatments for Alloy 22 (UNS N06022) were suggested by previous studies [7,8] performed at Lawrence Livermore National Laboratory (LLNL) to produce detrimental second phases, as shown in Table 4. (Note: Due to the time required for the heat treatment of the LRO specimens, they were added to the autoclave several weeks after the Keno testing initiated. This difference in testing time for the LRO specimens is evident in the time-to-failure plots to be presented). Optical microscopy and TEM were performed for the materials used in Run 2 to determine the effect of the heat treatments on the resulting Alloy 22 (UNS N06022) microstructure. The microstructure of mill annealed Alloy 22 (UNS N06022) consists of an FCC solid solution with occasional $\mathrm{M}_{6} \mathrm{C}$ carbides distributed throughout the matrix [2], as shown in Figure 6. (Note that carbides were not observed in this study). Optical metallography for the heat treated and welded conditions is also shown in Figure 6. TCP phases and long range ordering (LRO) were not observed by optical microscopy. Higher magnification TEM was used to investigate the possible presence of small precipitates not visible by optical microscopy. Asreceived Alloy 22 (UNS N06022) contained a low density of dislocations but no precipitates, as shown in Figure 7. Mo-rich grain boundary precipitates were observed in the as-received $+\mathrm{HT} 1\left(700^{\circ} \mathrm{C} / 175\right.$ hr) material (Figure 7). No precipitates were observed in the matrix. The as-received $+\mathrm{HT} 2\left(520^{\circ} \mathrm{C} /\right.$ $1000 \mathrm{hr}$ ) material contained a high density of fine, coherent $\mathrm{Ni}_{2}(\mathrm{Cr}, \mathrm{Mo})$ phase, as did the as-received + cold worked $+\mathrm{HT} 2$ material, also shown in Figure 7. Additional TEM using dark field imaging is currently in progress to discern the effect of cold work on the relative amount and size of the ordered $\mathrm{Ni}_{2}(\mathrm{Cr}, \mathrm{Mo})$ phase.

Welded specimens were centered on the fusion line so that the specimen gage included both the weld and the heat affected zone (HAZ), as shown by the schematic in Figure 8. In an effort to produce a tight crevice on the tensile specimen surfaces, creviced specimens were plastically pre-strained to $93 \%$ of the intended SCC experiment stress. After pre-straining, crevices were produced using 0.75 inch diameter Teflon barstock that had the center drilled out to the diameter specification of its respective 
specimen. The Teflon cylinders were then cut in half lengthwise and the two halves were clamped onto the specimens using stiff titanium wire. Diffusion of oxygen through bulk Teflon at $105^{\circ} \mathrm{C}$ was assumed negligible.

A multiple-notch specimen design was added to the Run 2 matrix for several Alloy 22 (UNS N06022) conditions. The design contains three circumferential U-shape grooves (notches), one in the gage center and one located either side the gage at a distance of 0.20 inch from the center notch, as shown in Figure 9. Finite Element Analyses (FEA) were performed to ensure that the stress fields of the multiple notched specimens were independent of each other and did not overlap. (Overlapping stress fields could reduce the stress concentration factor of the middle notch). The FEA determined that a notch inter-distance of 0.2 inches would produce independent notch stress fields; this distance was used in the selected specimen design. FEA results corresponded well with elastic stress concentration calculations performed at GE GRC, where the calculated stress concentration factors were 3.55 (FEA) and 3.38 (GE GRC calculation).

Based on the experience gained in Run 1, several modifications were made to improve the Keno systems prior to the Full Run 2. A new pressure regulator was installed to provide better control of the system pressure. The system temperature was lowered to $105^{\circ} \mathrm{C}$, which is slightly less than the solution boiling point. This change in temperature prevented salt deposit formation on the manifold, allowing the balls to freely fall and to be correctly recorded by the data acquisition system. An improved system for monitoring autoclave solution level was installed. Additionally, a pressure transducer was installed, allowing computer acquisition and close monitoring of pressure data. Installation of a back pressure regulator was added as a safety measure.

Keno Run \#2 has produced 40 specimen failures during the $8686 \mathrm{hrs}$ of exposure to date, as shown in Figure 10. Note that time zero begins at 1000 psi in Figure 10, and that the pressure was increased to $1500 \mathrm{psi}$ (the target value) at $168.5 \mathrm{hrs}$. Several sensitized 304 stainless steel and Titanium Grade 7 failures occurred soon after the increase at $168.5 \mathrm{hrs}$, suggesting that $168.5 \mathrm{hrs}$ may be a more accurate "time zero". However, time zero was not adjusted since sensitized 304 stainless steel failures occurred at $\mathrm{t}<168.5 \mathrm{hrs}$, and there was not a obvious method for how to normalize this data. Increased applied stress decreased time-to-failure for the as-received Titanium Grade 7 specimens, as shown in Figure 10. Note that one as-received Titanium Grade 7 specimen remains unfailed after $>6140 \mathrm{hr}$. The composition of this specimen was confirmed by semiquantitive $\mathrm{X}$-ray analysis.

Several unfailed specimens were removed for closer observation at 2462 hours, including asreceived 316NG stainless steel, as-received Alloy 22 (UNS N06022), LRO Alloy 22 (UNS N06022), TCP Alloy 22 (UNS N06022), and welded Alloy 22 (UNS N06022) specimens in the highest stress conditions (31 specimens total). All removed specimens were shiny with no evidence of corrosion or cracking. Additionally, dye penetrant revealed no SCC cracks or large pits on the surfaces of these specimens. Limited small regions of damage (finer than the surface finish) were observed on some of the specimens (both $316 \mathrm{NG}$ and Alloy 22 (UNS N06022)), but it is not known if the damage was produced during machining or during the environmental cracking experiment. All specimens except for three used for additional characterization were returned to their original positions in the autoclave manifolds.

Due to the lack of SCC failures to date for the uncreviced and creviced Alloy 22 (UNS N06022) and $316 \mathrm{NG}$ materials, meaningful statistical analysis on these materials is not possible at this time. The 
lack of SCC failures in Alloy 22 (UNS N06022) under high applied stress in high temperature, concentrated mixed salt solution corroborates the high environmental cracking resistance (but not immunity) reported for this material using precracked compact tension specimens under constant load in similar environment $[1,2,9]$.

\section{CONCLUSIONS}

Alloy 22 (UNS N06022) and 316NG exhibit excellent SCC resistance after $4500-8700 \mathrm{hrs}$ exposure in hot concentrated salt solution $\left(\mathrm{pH}=10.3\right.$ at $\left.105^{\circ} \mathrm{C}\right)$ designed to simulate the chemistry of concentrated Yucca Mountain ground water, as shown by constant load tests on smooth, creviced, and notched tensile specimens in several microstructural conditions. Sensitized 304 stainless steel is highly susceptible to SCC in this environment. Titanium Grade 7 is susceptible to SCC in this environment, particularly at very high \%TS. Shot peening did not affect time-to-failure for sensitized 304 stainless steel and Titanium Grade 7. To date, an effect of surface roughness on time-to-failure has not been observed.

\section{ACKNOWLEDGEMENTS}

This paper was prepared to document work performed by GE Global Research for the U.S. DOE Yucca Mountain Project, Bechtel SAIC Corporation (BSC), under Purchase Order No. 2450-100-PO-10508. Finite Element Analyses (FEA) were performed for the notched specimen geometry by Mishko Mastilovic at BSC. Necip Doganaksoy at GE Global Research provided Weibull statistical analyses for the failed specimens in Run 1 . These contributions are gratefully acknowledged.

\section{REFERENCES}

1. P.L. Andresen, P.W. Emigh, L.M. Young, and G.M. Gordon, "Stress Corrosion Cracking of Annealed and Cold Worked Titanium Grade 7 and Alloy 22 in $110^{\circ} \mathrm{C}$ Concentrated Salt Environments", Corrosion/ 2001, Paper No. 1130, Houston, TX, NACE.

2. P.L. Andresen, L.M. Young, G.M. Gordon, "SCC Growth Rate Behavior of Alloy 22 in Concentrated Groundwater", these proceedings, Corrosion/2003, Paper No. 03683, Houston, TX, NACE.

3. Y.J. Kim, P.L. Andresen, P.J. Martiniano, J.Chera, M. Larsen and G.M. Gordon, "Passivity of Nuclear Waste Canister Candidate Materials in Mixed-Salt Environments", Corrosion/2002, Paper No. 02544, Houston, TX, NACE.

4. C.S. Brossia and G.A. Cragnolino, "Effects of Environmental Electrochemical, and Metallurgical Variables on the Passive and Localized Dissolution of Ti Grade 7," Paper No. 0211, Corrosion/2000, Houston, TX, NACE.

5. D.S. Dunn, C.S. Brossia and O. Pensado, "Long-Term Dissolution Behavior of Alloy 22: Experiments and Modeling," Paper No. 1125, Corrosion/2001, Houston, TX, NACE.

6. B.A. Kehler, G.O. Ilevbare, and J.R. Scully, "Crevice Corrosion Stabilization and Repassivation Behavior of Alloys 625 and 22," Paper No. 1141, Corrosion/2001, Houston, TX, NACE.

7. T.S.E. Summers, M.A. Wall, M. Kumar, S.J. Matthews, and R.B. Rebak, "Phase Stability and Mechanical Properties of Alloy 22 Alloy Aged in the Temperature Range 590 to $760^{\circ} \mathrm{C}$ for 16,000 hours," Lawrence Livermore National Laboratory Report \#UCRL-JC-130816, in Scientific Basis for Nuclear Waste Management XXII, ed. by David J. Wronkiewicz and Joon H. Lee, Materials Research Society (1999), 919-926.

8. T.S.E. Summers, personal communication, December 2000.

9. J.C. Estill, K.J. King, D.V. Fix, D.G. Spurlock, G.A. Must, S.R. Gordon, R.D. McCright, R. Rebak, and G.M. Gordon, "Susceptibility of Alloy 22 to Environmentally Assisted Cracking in Yucca Mountain Relevant Environments", Paper No. 02535, Corrosion/2002, Houston, TX, NACE. 
Table 1. Molar Composition of Keno Solution (M)

\begin{tabular}{|c|c|c|c|c|c|c|}
\hline $\mathrm{Na}_{2} \mathrm{CO}_{3}$ & $\mathrm{KCl}$ & $\mathrm{NaCl}$ & $\mathrm{NaF}$ & $\mathrm{NaNO}_{3}$ & $\mathrm{Na}_{2} \mathrm{SO}_{4}$ & $\mathrm{Na}_{2} \mathrm{SiO}_{3} .9 \mathrm{H}_{2} \mathrm{O}$ \\
\hline 0.27 & 0.35 & 0.41 & 0.013 & 0.43 & 0.03 & 0.04 \\
\hline
\end{tabular}

Table 2. Tensile Properties in Air

\begin{tabular}{|l|c|c|}
\hline \multicolumn{1}{|c|}{ Material/Condition } & $\begin{array}{c}\text { Yield Strength } \\
(\mathrm{ksi})\end{array}$ & $\begin{array}{c}\text { Tensile Strength } \\
(\mathrm{ksi})\end{array}$ \\
\hline Alloy 22(UNS N06022) As received & $47\left(125^{\circ} \mathrm{C}\right)$ & $104\left(125^{\circ} \mathrm{C}\right)$ \\
\hline $\begin{array}{l}\text { Alloy 22 (UNS N06022) As received + 20\% } \\
\mathrm{CW}\end{array}$ & $125\left(125^{\circ} \mathrm{C}\right)$ & $133\left(125^{\circ} \mathrm{C}\right)$ \\
\hline $\begin{array}{l}\text { Alloy 22 (UNS N06022) As received + HT1 } \\
\left(700^{\circ} \mathrm{C} / 175 \mathrm{~h}\right)\end{array}$ & $49\left(105^{\circ} \mathrm{C}\right)$ & $107\left(105^{\circ} \mathrm{C}\right)$ \\
\hline $\begin{array}{l}\text { Alloy 22 (UNS N06022) As received + HT2 } \\
\left(520^{\circ} \mathrm{C} / 1000 \mathrm{~h}\right)\end{array}$ & $70\left(105^{\circ} \mathrm{C}\right)$ & $149\left(105^{\circ} \mathrm{C}\right)$ \\
\hline $\begin{array}{l}\text { Alloy 22 (UNS N06022) 20\% CW + HT2 } \\
\left(520^{\circ} \mathrm{C} / 1000 \mathrm{~h}\right)\end{array}$ & $133\left(105^{\circ} \mathrm{C}\right)$ & $179\left(105^{\circ} \mathrm{C}\right)$ \\
\hline $316 N G$ As received & $28.7\left(125^{\circ} \mathrm{C}\right)^{*}$ & - \\
\hline Titanium Gr 7 As-teceived & $36\left(125^{\circ} \mathrm{C}\right)$ & $53\left(125^{\circ} \mathrm{C}\right)$ \\
\hline Titanium Gr 7 20\% CW & $72.5\left(125^{\circ} \mathrm{C}\right)$ & $75.5\left(125^{\circ} \mathrm{C}\right)$ \\
\hline $304 S S$ Sensitized $\left(621^{\circ} \mathrm{C} / 24 \mathrm{~h}\right)$ & $42.5\left(125^{\circ} \mathrm{C}\right)$ & $75\left(125^{\circ} \mathrm{C}\right)$ \\
\hline
\end{tabular}

* Interpolated using RT and $288^{\circ} \mathrm{C}$ data

Table 3. Initial Run 1 Matrix

\begin{tabular}{|l|l|c|c|}
\hline \multicolumn{1}{|c|}{ Material } & \multicolumn{1}{|c|}{ Condition } & $\begin{array}{c}\text { Max Applied Stress } \\
\text { (ksi) }\end{array}$ & $\begin{array}{c}\text { Total } \\
\text { Specimens }\end{array}$ \\
\hline $\begin{array}{l}\text { Alloy 22 } \\
\text { (UNS N06022) }\end{array}$ & As-received & 115 & 6 \\
\hline & AR + 20\% cold work & 115 & 6 \\
\hline & AR + shot peened & 115 & 4 \\
\hline Ti-Grade 7 & As-received & $49,56^{*}$ & 6 \\
\hline & AR + 20\% CW & 67,88 & 6 \\
\hline NG 316 SS & AR + shot peened & $49,56^{*}$ & 4 \\
\hline & As-received & 69,90 & 4 \\
\hline 304SS & AR + shot peened & 69 & 6 \\
\hline & Sensitized & 54,60 & 4 \\
\hline Total & Sensitized + shot peened & 54,60 & 50 \\
\hline
\end{tabular}

* Some Ti Gr7 specimens were knowingly ductile overloaded; autoclave pressure was purposely increased at $282.5 \mathrm{hrs}$ in order to facilitate SCC initiation in C22 specimens. 
Table 4. Full Autoclave Run Matrix (Run 2)

\begin{tabular}{|c|c|c|c|c|c|c|}
\hline Material & Condition & Finish & \multicolumn{3}{|c|}{ Specimens per Condition } & $\begin{array}{c}\text { Total } \\
\text { Specimens }\end{array}$ \\
\hline & & & \multicolumn{3}{|c|}{ System Pressure $=1500$ psi } & \\
\hline $\begin{array}{l}\text { Alloy } 22 \\
\text { (UNS N06022) }\end{array}$ & & RMS & $85 \mathrm{ksi}$ & $93 \mathrm{ksi}$ & $100 \mathrm{ksi}$ & \\
\hline & As-received & 150 & 6 & 6 & 6 & 18 \\
\hline & As-received & 72 & & 6 & & 6 \\
\hline & $\mathrm{AR}+\mathrm{HT} 1\left(700^{\circ} \mathrm{C} / 175 \mathrm{~h}\right)$ & 150 & 6 & 6 & & 12 \\
\hline & $\mathrm{AR}+\mathrm{HT} 2\left(520^{\circ} \mathrm{C} / 1000 \mathrm{~h}\right)$ & 150 & 6 & 6 & & 12 \\
\hline & $\mathrm{AR}+20 \% \mathrm{CW}+\mathrm{HT} 2$ & & & 6 & & 6 \\
\hline & $20 \%$ Cold worked & & & 6 & & 6 \\
\hline & AR + Creviced & 150 & 6 & 6 & & 12 \\
\hline & $\mathrm{AR}+\mathrm{HT} 1+$ Creviced & 150 & 6 & 6 & & 12 \\
\hline & Weld and $\mathrm{HAZ}$ & 150 & 6 & 6 & & 12 \\
\hline Ti-Grade 7 & & & $40 \mathrm{ksi}$ & $45 \mathrm{ksi}$ & $50 \mathrm{ksi}$ & \\
\hline & As-received & 150 & 6 & 6 & 5 & 17 \\
\hline & Creviced & 150 & & 6 & & 6 \\
\hline NG 316 SS & & & $65 \mathrm{ksi}$ & $70 \mathrm{ksi}$ & & \\
\hline & As-received & 150 & 6 & 6 & & 12 \\
\hline & As-received & 72 & & 6 & & 6 \\
\hline & Creviced & 150 & & 6 & & 6 \\
\hline $304 S S$ & & & $45 \mathrm{ksi}$ & $50 \mathrm{ksi}$ & & \\
\hline & Sensitized $\left(621^{\circ} \mathrm{C} / 24 \mathrm{~h}\right)$ & 150 & 6 & 6 & & 12 \\
\hline & Sensitized + creviced & 150 & & 6 & & 6 \\
\hline Total & & & & & & 161 \\
\hline & & & & $\begin{array}{c}\text { Effective } \\
\text { stress } \\
85 \mathrm{ksi} \\
\end{array}$ & & \\
\hline Alloy 22 notched & As-received & 150 & & 8 & & 8 \\
\hline Alloy 22 notched & As-received $+700^{\circ} \mathrm{C} / 175 \mathrm{~h}$ & 150 & & 8 & & 8 \\
\hline Alloy 22 notched & Weld and HAZ & 150 & & 8 & & 8 \\
\hline $\begin{array}{l}\text { Grand Total } \\
\text { Full Matrix }\end{array}$ & & & & & & 185 \\
\hline
\end{tabular}




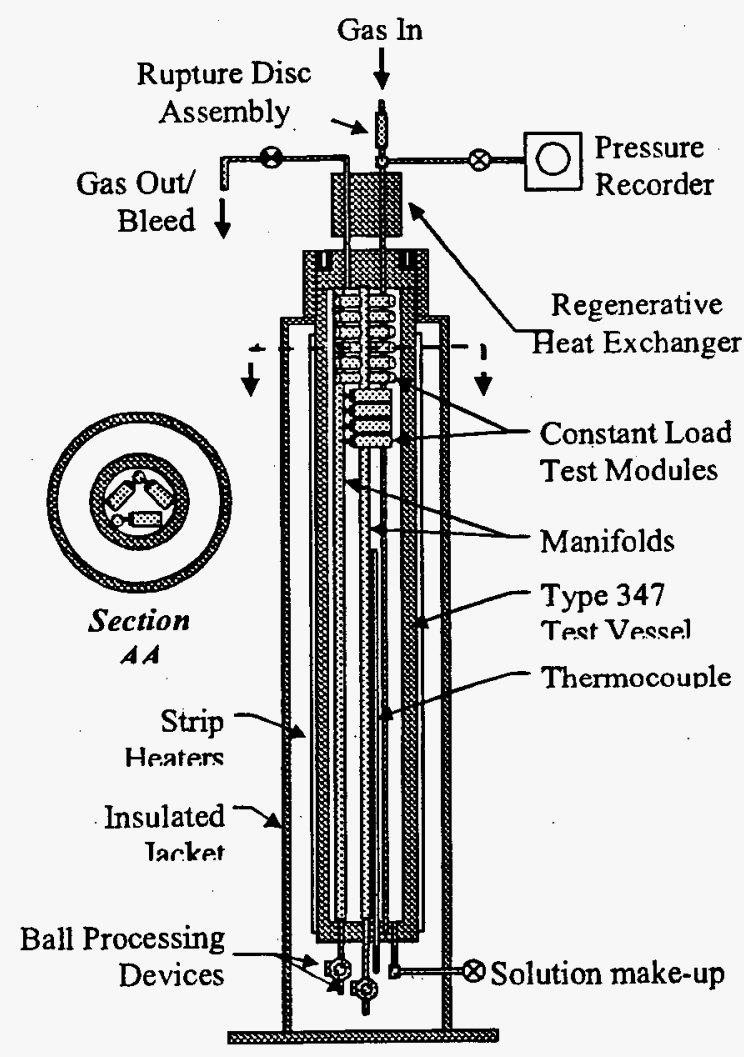

Figure 1. Schematic cross section of Keno autoclave for smooth constant load testing.

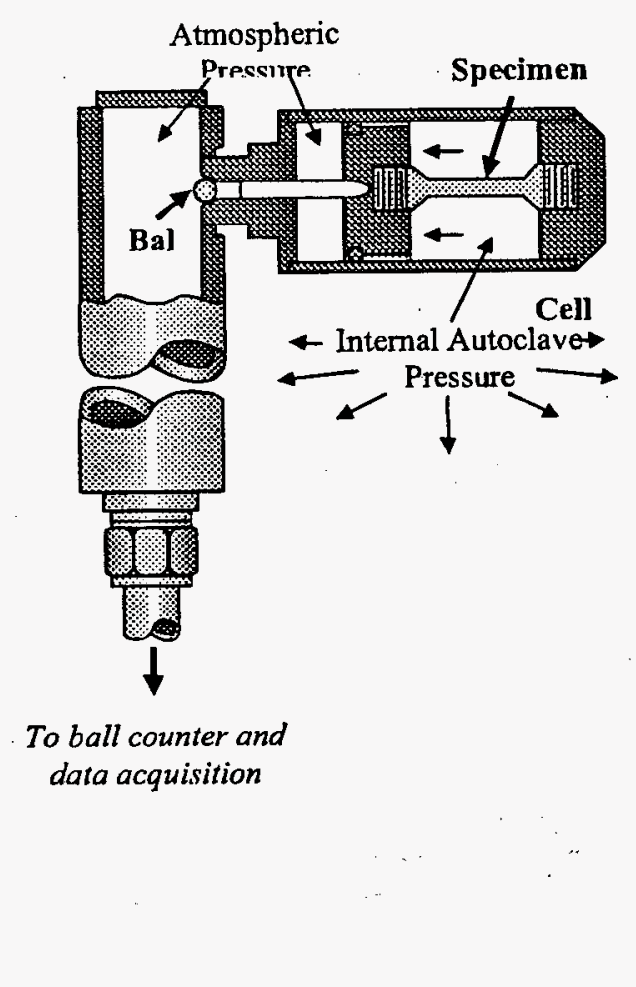

Figure 2. Schematic cross section of Keno smooth constant load module assembly and tensile specimen illustrating the loading technique of differential pressure. 


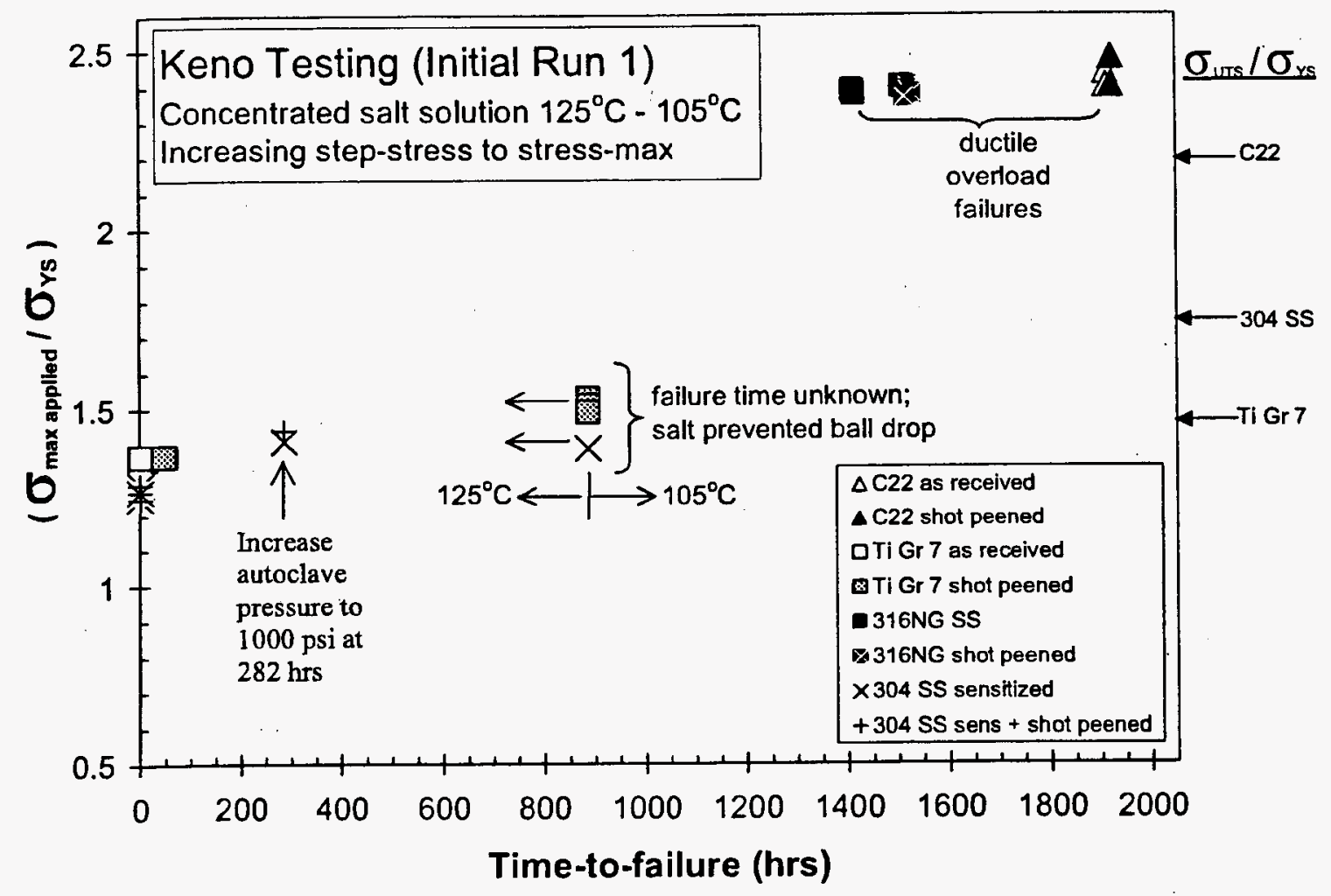

Figure 3. Time-to-failure vs: applied stress ratio for Initial Run 1. Salt deposit formation prevented failure time acquisition for several failures at $125^{\circ} \mathrm{C}$. System overload (due to a faulty pressure regulator) produced ductile overload failures in the Alloy 22 (UNS N06022) specimens. 


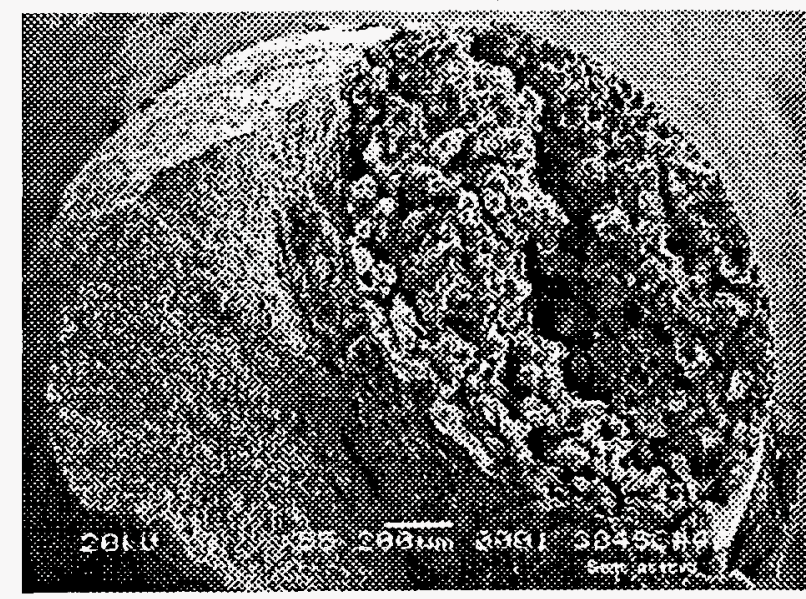

(a)

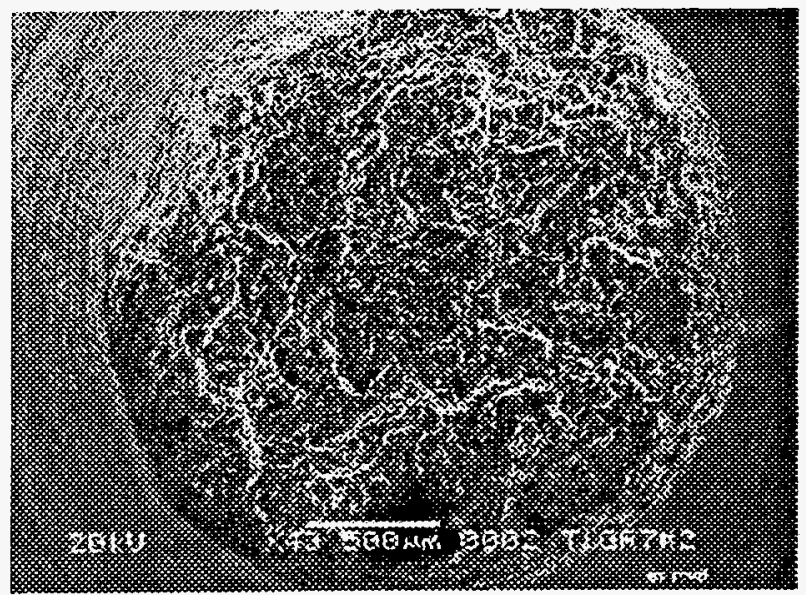

(c)

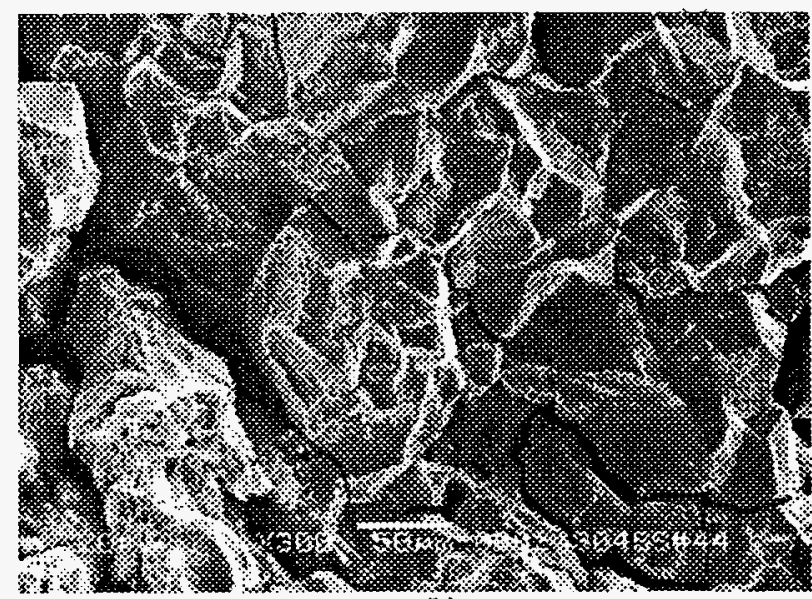

(b)

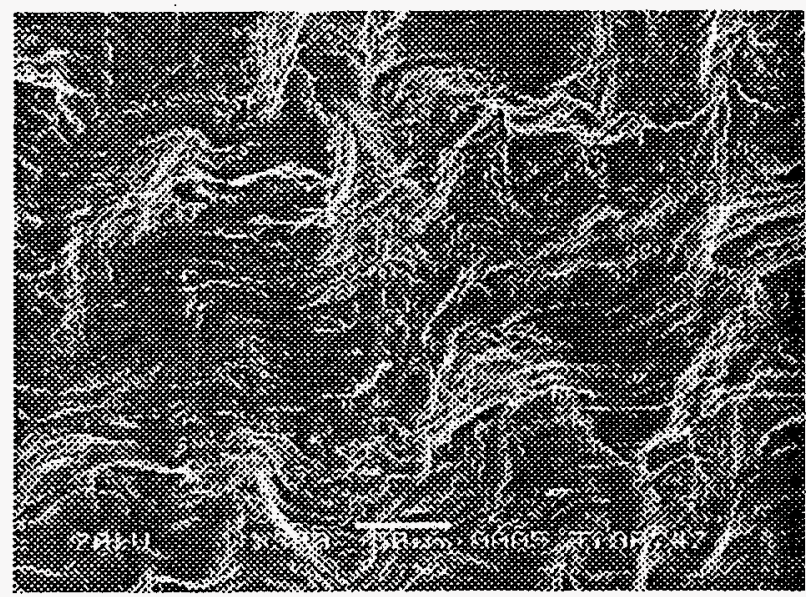

(d)

Figure 4. SCC surfaces for failed Keno specimens (a) and (b) Sensitized 304SS; (c) and (d) Titanium Gr7. 


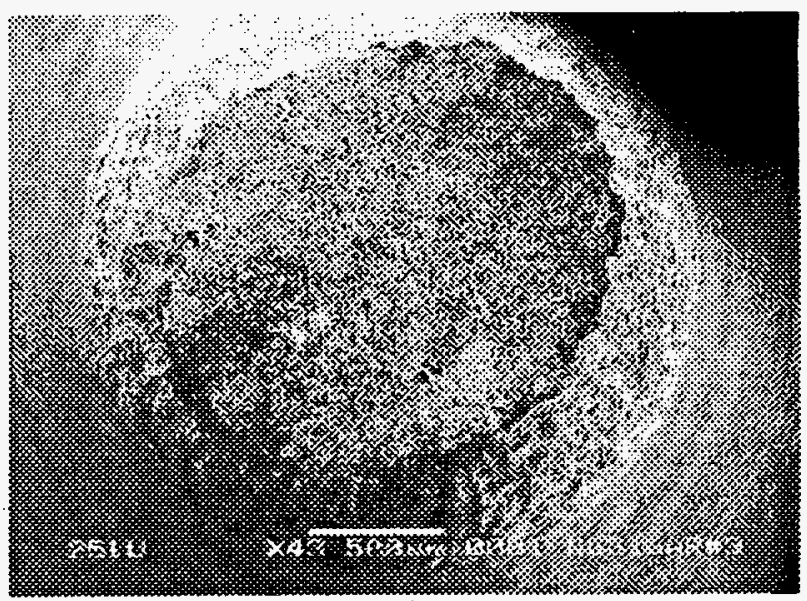

(a)

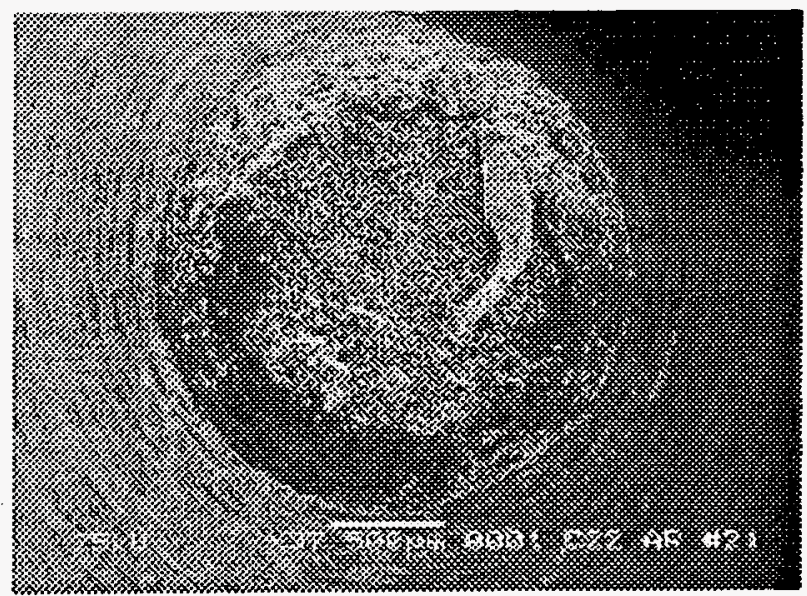

(c)

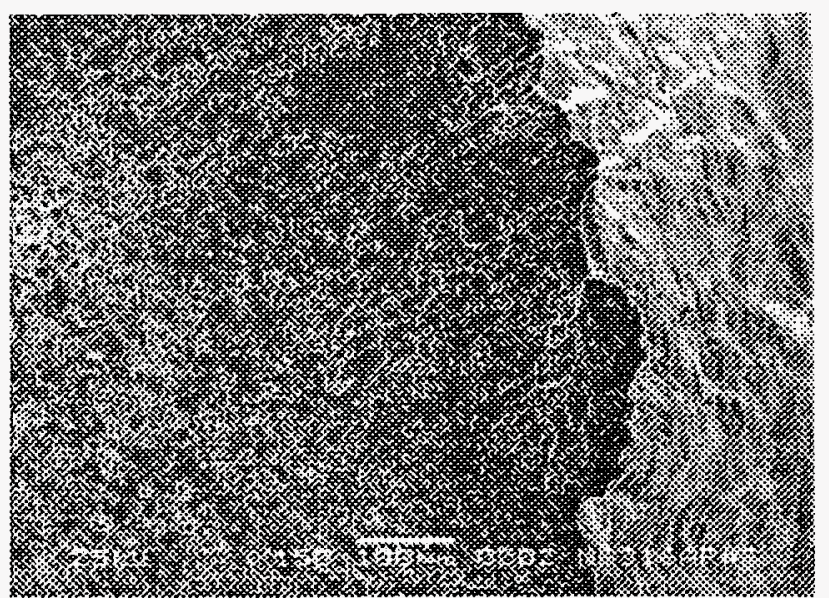

(b)

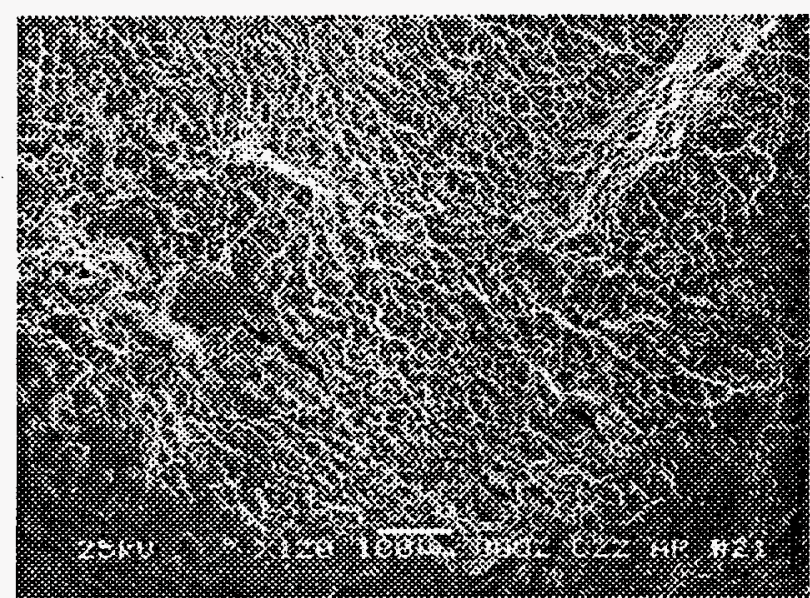

(d)

Figure 5. Fracture surfaces of ductile overload failures of Keno specimens (a) and (b) 316 NG stainless steel; (c) and (d) Alloy 22 (UNS N06022). 


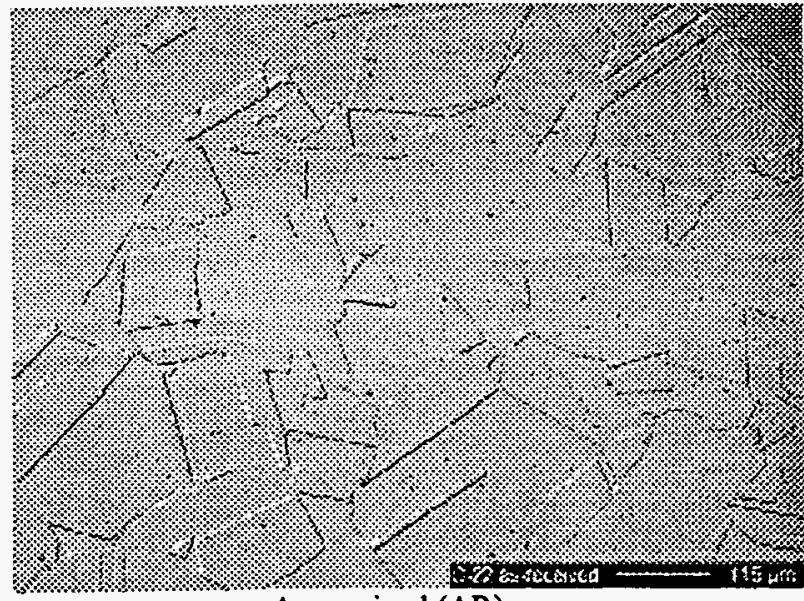

As-received (AR)

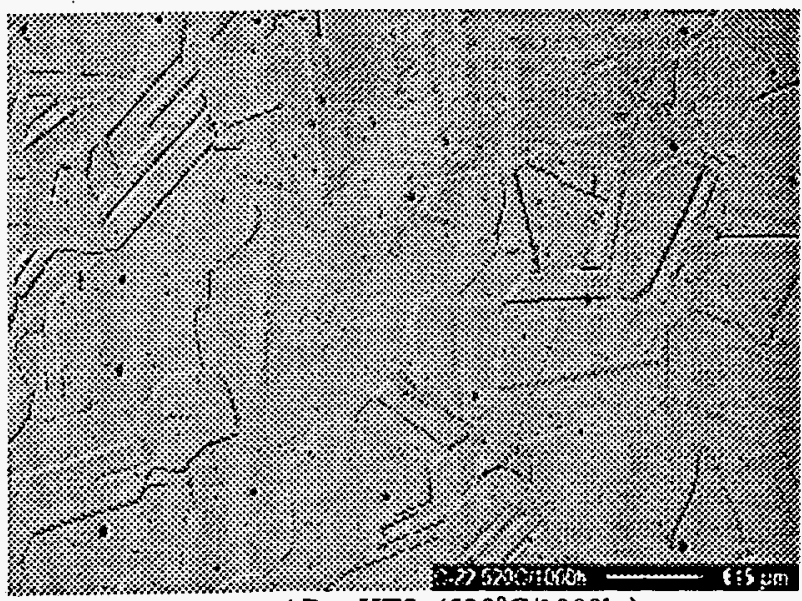

$\mathrm{AR}+\mathrm{HT} 2\left(520^{\circ} \mathrm{C} / 1000 \mathrm{hr}\right)$


$\mathrm{AR}+20 \%$ cold work + HT2 $\left(520^{\circ} \mathrm{C} / 1000 \mathrm{hr}\right)$

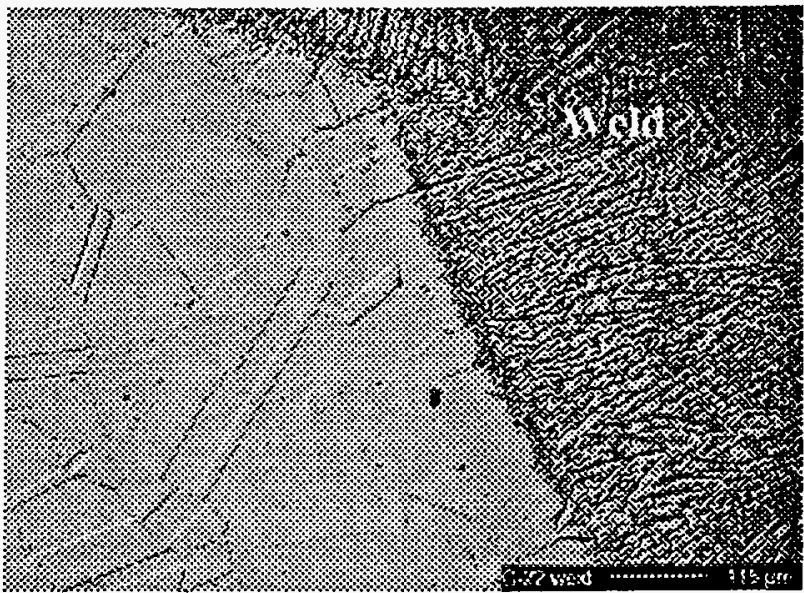

AR Weld Fusion Region

Figure 6. Optical metallography of Alloy 22 (UNS N06022) heat treatments used in Keno Run 2. Etched with 10g oxalic acid in water at $\sim 6 \mathrm{~V}$ for 5-15 seconds. Viewed using differential interference contrast (DIC). 


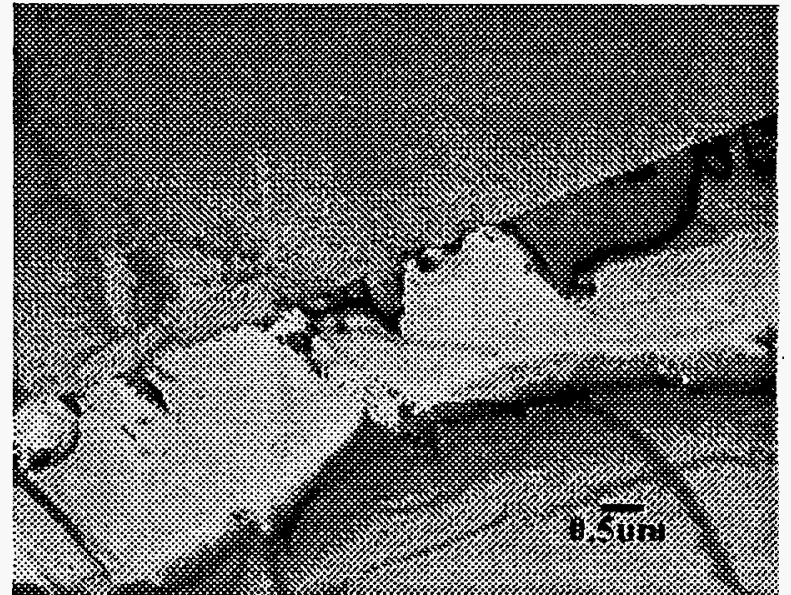

As-received (AR)

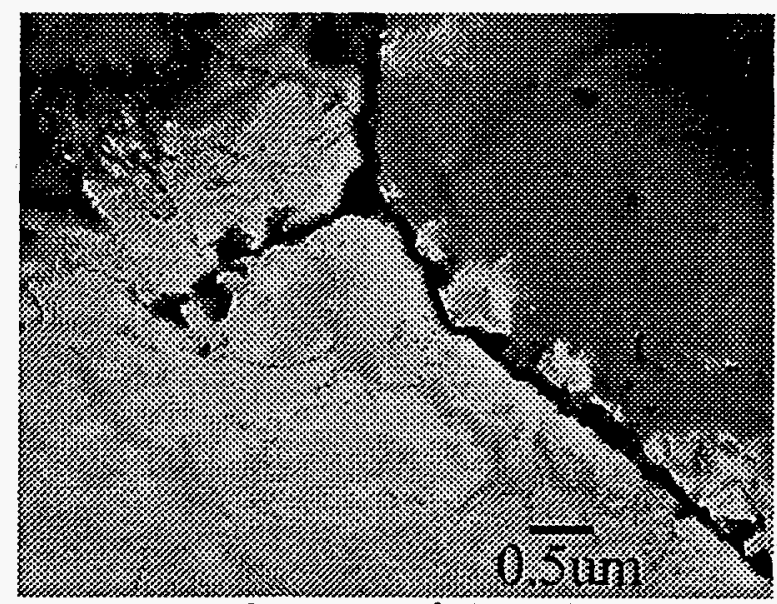

$\mathrm{AR}+\mathrm{HT} 1\left(700^{\circ} \mathrm{C} / 175 \mathrm{hr}\right)$

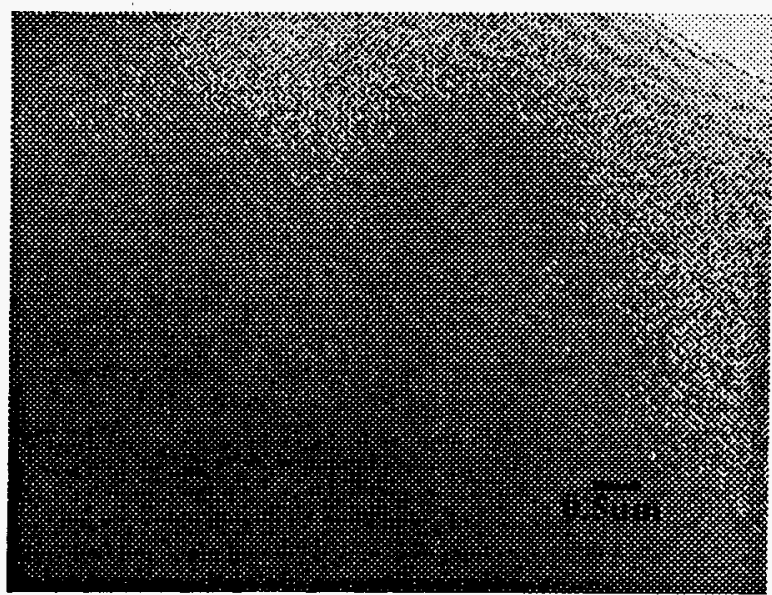

$\mathrm{AR}+\mathrm{HT} 2\left(520^{\circ} \mathrm{C} / 1000 \mathrm{hr}\right)$

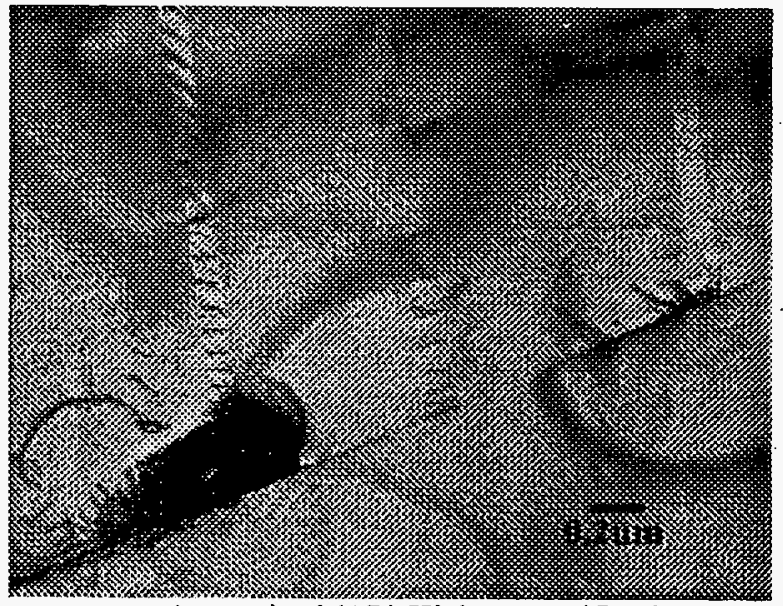

As-received (AR) Higher magnification

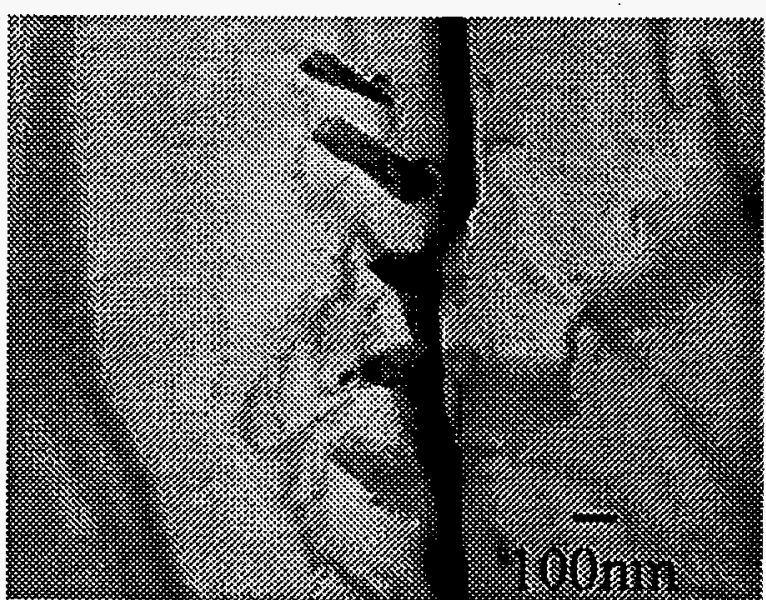

$\mathrm{AR}+\mathrm{HT} 1\left(700^{\circ} \mathrm{C} / 175 \mathrm{hr}\right)$ Higher magnification

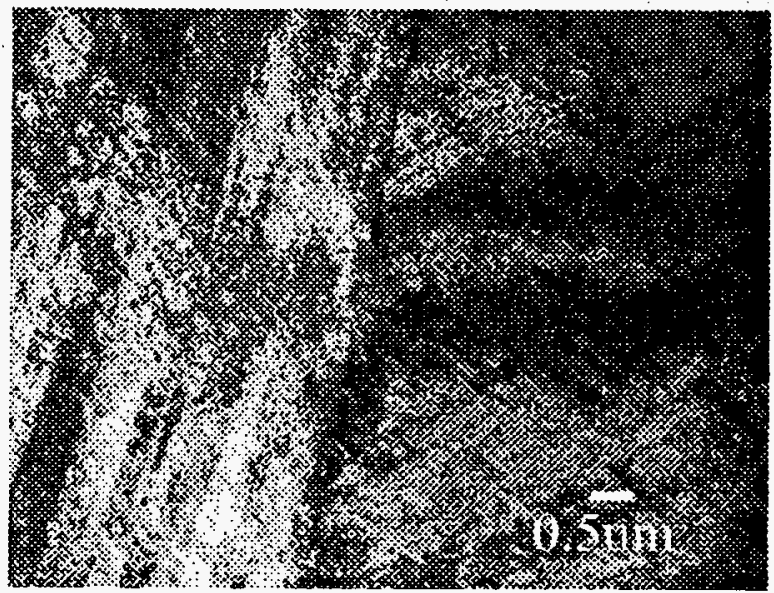

$\mathrm{AR}+20 \%$ cold work $+\mathrm{HT} 2\left(520^{\circ} \mathrm{C} / 1000 \mathrm{hr}\right)$

Figure 7. Transmission electron microscopy (TEM) images of Alloy 22 (UNS N06022) in the as-received and beat treated conditions. 


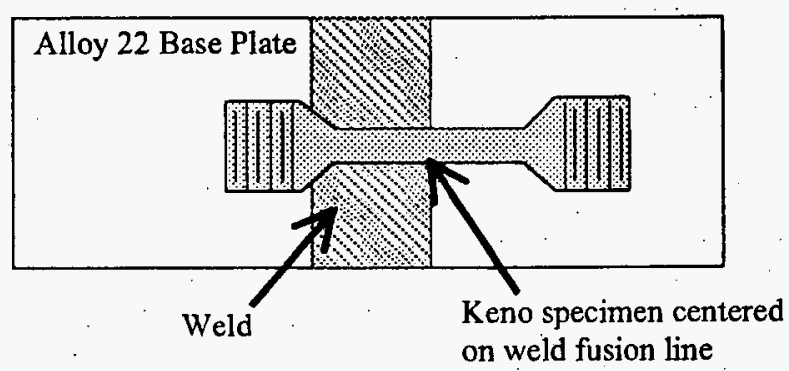

Figure 8. Schematic of Keno specimen placement in Alloy 22 (UNS N06022) welded plate. Tensile loading direction is perpendicular (transverse) to weld pass direction.

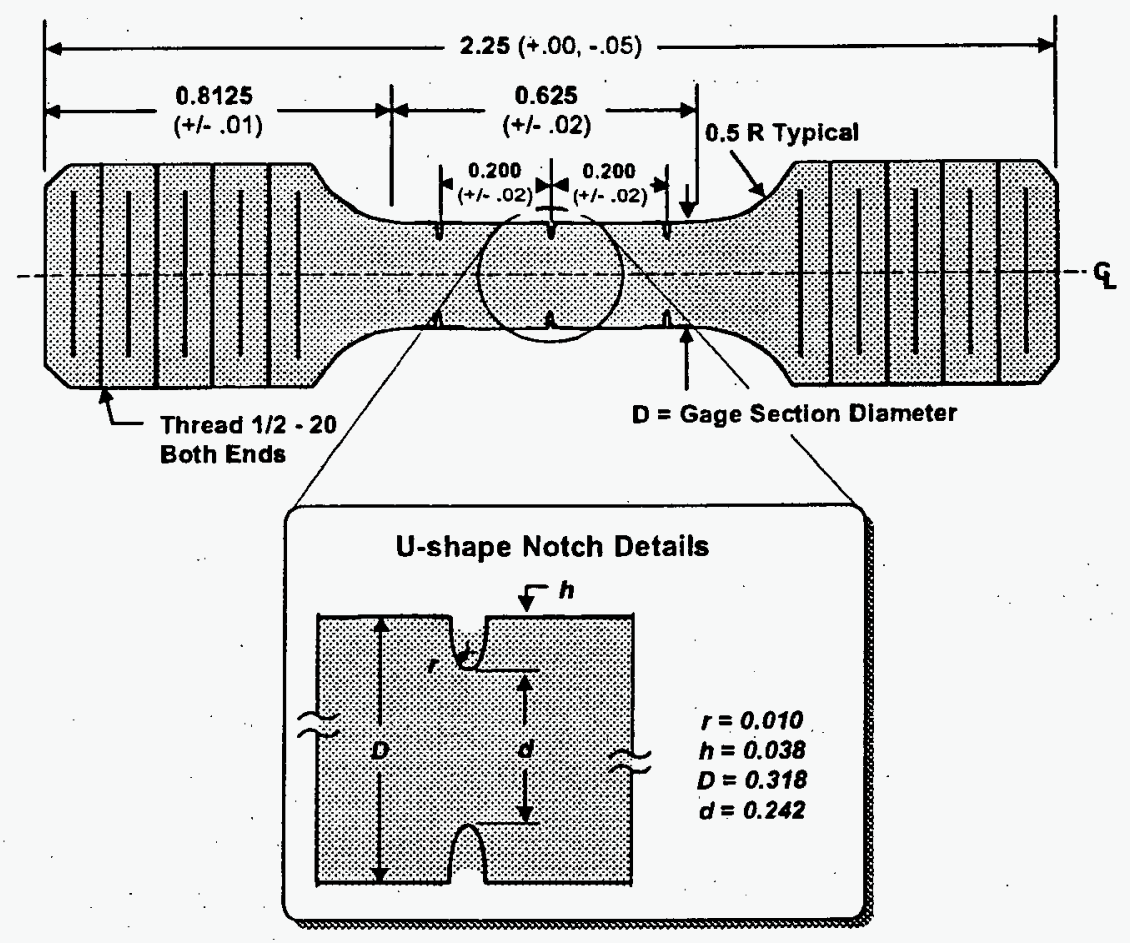

Figure 9. Notched Keno specimen drawing used for 24 specimens in Keno Run 2. 


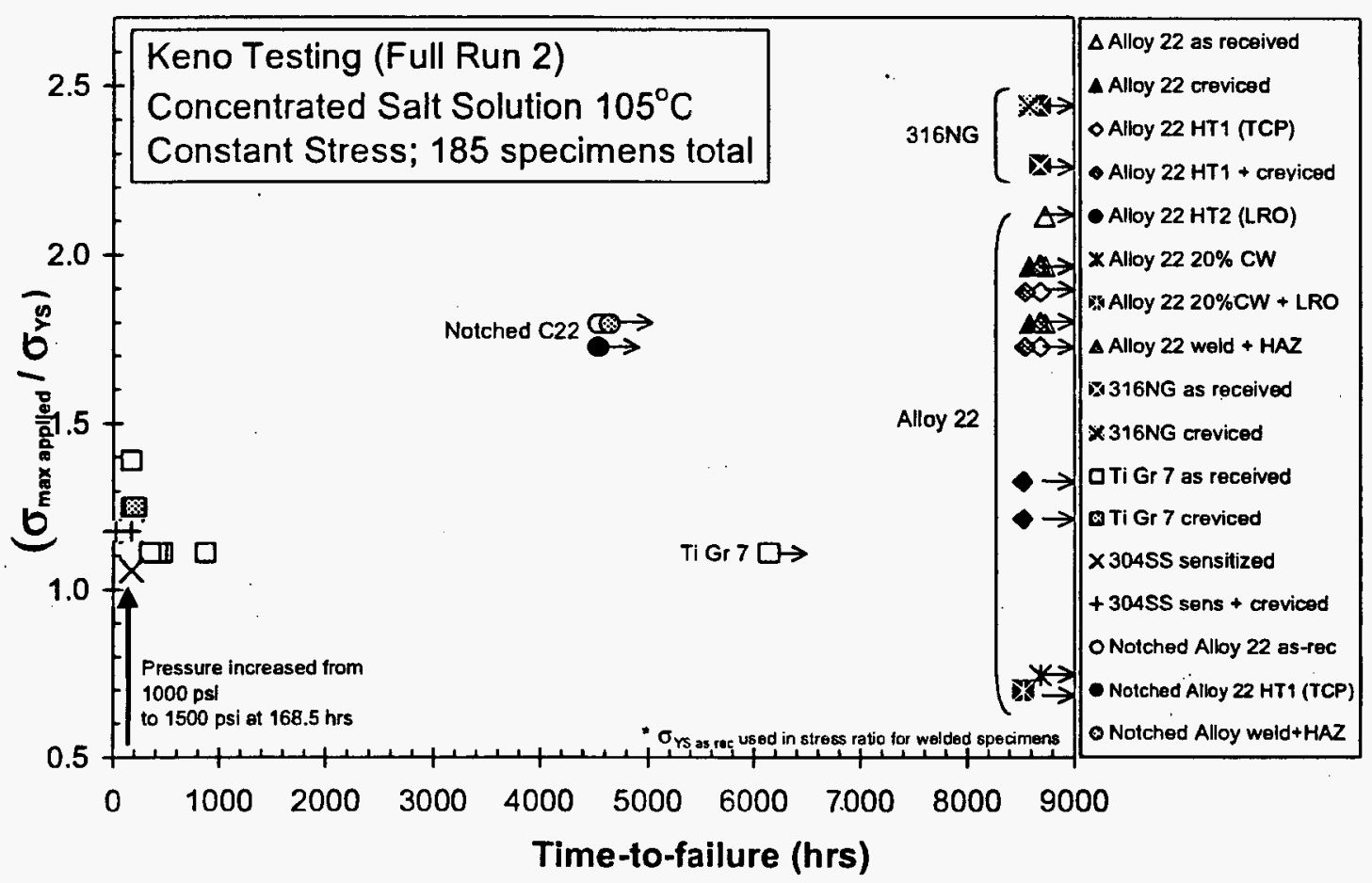

Figure 10. Time-to-failure vs. Applied stress ratio for Full Matrix Run 2. Forty specimens have failed to date. 